\title{
December Meetings of the Business Historical Society
}

The Business Historical Society will meet late in December in joint session with two national associations, the American Historical Association and the American Economic Association. These meetings will be of interest to both business historians and business men; the subjects discussed are close to the heart of the activities of each group.

The meeting with the American Economic Association will be held at the Hotel Commodore in New York on Sunday afternoon, December 28. This meeting will be in the nature of an informal discussion conference. Professor Ralph M. Hower, a member of the Business Historical Society, will present a paper on "The Effect of Managerial Policy upon the Structure of American Business." Discussion will be led by Professor C. H. Ashley, of the University of Toronto, Professor Charles W. Phillips, of Colgate University, and Professor Fritz Redlich, of Mercer College.

The joint session with the American Historical Association will be held on Monday morning, December 29, at the Stevens Hotel in Chicago. Mr. Harold H. Swift of Chicago, a member of the Business Historical Society, will preside. Professor N. S. B. Gras, also a member of the Society, will present the paper of the occasion. Its subject is "Capitalism: Concept and History." Discussion of the paper will be led by Dr. D. C. Creighton, of the University of Toronto, Mr. Raymond de Roover, of Jacksonville, Illinois, and Dr. Henrietta M. Larson, member of the Business Historical Society and editor of its Buldetin. A luncheon meeting, arranged by the Business Historical Society to follow the morning session, will continue the discussion.

Business administration will be the central interest in both meetings. Professor Gras will treat the subject in its larger historical meaning, while Professor Hower will deal with one aspect of administration, that is, management, in relation to American experience. This emphasis on business administration is obviously a timely one, for in the years that lie ahead it is likely to grow in importance along with an increasing emphasis on political administration. 